\title{
PESANTREN DAN TANTANGAN MODERNISASI \\ DALAM BUKU MENGGERAKKAN TRADISI KARYA KH. ABDURRAHMAN WAHID
}

\author{
Isnaning Tyastuti \\ Mahasiswa Pascasarjana Institut Agama Islam Sunan Giri Ponorogo \\ Email : isnaningtyas20@gmail.com
}

\begin{abstract}
Pesantren is a traditional Islamic education institution, is an original institution that is owned by Indonesia and has its own unique characteristics. It is said to be unique because the pesantren has a traditional education mechanism tecnicals and has a tradition that not all educational institutions have. The rapid flow of globalization has threatened the existence of pesantren, so that the concept of modernization emerged in the pesantren environment to answer the challenges of the all-modern globalization in all aspects. This study aims to show a comprehensive picture, idea, and concept in the attitude of pesantren facing the era of modernization so that the existence of boarding schools remains by combining the concept of traditional education with modern education without leaving the characteristics of pesantren education that has become the identity of a pesantren. This research is a qualitative study of literature (library research) using documentation methods and using the type of taxonomy analysis that is analysis that focuses attention on a particular domain that is very useful to describe the phenomenon or problem that is the target of the study. This research resulted in modernization described by $\mathrm{KH}$. Abdurrahman Wahid is a response to the condition of Islamic Education, especially pesantren in the present. Modernization is conceptualized in order to provide input or solutions to Islamic education, especially pesantren, so that its existence is maintained in the current era of globalization. The existence of pesantren with the challenges of modernization according to $\mathrm{KH}$. Abdurrahman Wahid must be defended by constantly developing pesantren from various aspects of economics, social culture, revitalization in scientific education, revitalization in humansizm dinamics education, and especially education in pesantren.
\end{abstract}

\begin{abstract}
Abstrak
Pesantren adalah lembaga pendidikan Islam tradisional, merupakan lembaga asli yang dimiliki Indonesia dan memiliki ciri khas tersendiri serta unik. Dikatakan unik karena pesantren memiliki pola mekanisme pendidikan yang tradisional dan memiliki tradisi yang tidak semua lembaga pendidikan miliki. Derasnya arus globalisasi telah mengancam eksistensi pesantren, sehingga muncul konsep modernisasi di lingkungan pesantren demi menjawab tantangan arus globalisasi yang serba modern di segala aspek. Penelitian ini bertujuan untuk menunjukkan gambaran, gagasan, serta konsep yang komprehensif dalam sikap pesantren menghadapi era modernisasi agar eksistensi pesantren tetap dengan
\end{abstract}


mengkombinasikan konsep pendidikan tradisional dengan pendidikan modern tanpa meninggalkan ciri pendidikan pesantren yang sudah menjadi jati diri sebuah pesantren. Penelitian ini adalah sebuah penelitian kualitatif kajian pustaka (library research) dengan menggunakan metode dokumentasi dan menggunakan jenis analisis taxonomy yaitu analisis yang memusatkan perhatian pada domain tertentu yang sangat berguna untuk menggambarkan fenomena atau masalah yang menjadi sasaran studi. Penelitian ini menghasilkan modernisasi yang dijelaskan oleh KH. Abdurrahman Wahid merupakan respon terhadap kondisi Pendidikan Islam khususnya pesantren di masa sekarang ini. Modernisasi dikonsep agar memberikan masukan atau solusi terhadap pendidikan Islam khususnya pesantren agar eksistensinnya tetap terjaga di era globalisasi yang terjadi saat ini. Eksistensi pesantren dengan adanya tantangan modernisasi ini menurut KH. Abdurrahman Wahid harus dipertahankan dengan terus-menerus mengembangkan pesantren dari berbagai aspek ekonomi, social budaya,dan terutama pendidikan di pesantren.

Keyword : Pesantren, Modernization, KH. Abdurrahman Wahid.

\section{PENDAHULUAN}

Dunia pesantren merupakan fenomena yang sangat menarik untuk diteliti. Lembaga yang dikatakan tradisional ini memiliki nilai- nilai pendidikan yang tinggi yang tidak banyak disadari dan diperhatikan oleh pendidikan formal pada umumnya. Pondok pesantren juga merupakan lembaga pendidikan yang unik, tidak saja karena keberadaanya yang sudah sangat lama, tetapi juga karena kultur, metode, jaringan yang diterapkan oleh lembaga agama tersebut. ${ }^{1}$ Dunia pesantren adalah dunia yang mewarisi dan memelihara tradisi Islam yang dikembangkan ulama dari masa ke masa, dan hal tersebut tidak terbatas pada periode tertentu dalam sejarah Islam, karenanya tidak sulit bagi dunia pesantren untuk melakukan penyesuaian terhadap berbagai perubahan yang terjadi. Maka itu kemampuan pesantren untuk tetap bertahan dalam setiap perubahan, bukan sekedar karena karakteristiknya yang khas, tetapi juga karena kemampuannya dalam melakukan perbaikan secara terus menerus.

Menghadapi era globalisasi dan informasi, pesantren dalam kapasitasnya sebagai lembaga pendidikan Islam yang memiliki akar tradisi yang kuat di masyarakat cukup menarik untuk kita cermati kembali.Dalam perspektif Islam,

\footnotetext{
${ }^{1}$ Mardiyah, Kepemimpinan Kyai Dalam Memelihara Budaya Organisasi), (Malang: Aditya Media Publishing, 2015), 1.
} 
pendidikan memainkan peranan yang sangat penting dalam meningkatkan sumber daya manusia dan menunjang tugasnya sebagai khalifah di muka bumi. Merupakan ranahnya pesantren dalam memperbaiki akhlak dan perkembangan ilmu keagamaan terhadap seluruh santri sebagai peserta didik yang mengenyam pendidikan di pesantren. Untuk itu, dalam perannya pesantren harus mampu berkembang dari berbagai aspek guna mewadai segala hal yang menjadi kebutuhan para santrinya pada era dimana teknologi dan ilmu pengetahuan mengalami perkembangan pesat. Berbagai cara dilakukan oleh pesantren dalam menghadapi era modern ini, salah satunya konsep modernisasi pada pondok pesantren. Modernisasi pendidikan Islam merupakan suatu konsep yang penuh perubahan. Dilihat dari perspektif perubahan dan perkembangan kebudayaan, kelembagaan pendidikan Islam sulit untuk survive tanpa modernisasi. ${ }^{2}$ Arus globalisasi tidak hanya berdampak pada sosial, politik, dan ekonomi saja tetapi berdampak juga pada dunia pendidikan.Kemajuan di bidang teknologi transformasi merupakan salah satu produk yang diunggulkan dalam arus global serta bentuk modernisasi teknologi, dan juga berpengaruh langsung pada pendidikan.Akan tetapi pengaruh ini bisa dalam bentuk negatif maupun bentuk positif. ${ }^{3}$ Peran pesantren dalam mengajarkan, mengarahkan, membimbing para santri dalam proses pendidikan keagamaan menjadi penentu bagaimana santri secara keseluruhan mampu membedakan berbagai hal negatif maupun positif serta cara menyikapi beberapa hal sebagai produk dari modernisasi era global.

Berbicara mengenai pesantren dan permasalahannya, maka kita akan diingatkan pada seorang kyai besar yang sudah tidak asing lagi di kalangan masyarakat di Indonesia yakni KH. AbdurrahmanWahid atau lebih akrab disapa Gus Dur.Tentu saja, khalayak sudah faham jikalau Abdurrahman Wahid adalah seorang yang berasal dari kalangan pesantren.Pemikiran beliau tentang pesantren dan karya karyanya banyak diadopsi hingga saat ini.Seperti halnya masalah

\footnotetext{
${ }^{2}$ Azyumardi Azra, PENDIDIKAN ISLAM Tradisi dan Modernisasi di Tengah Tantangan Milenium III(Jakarta: Prenada Media Group, 2012), 38.

${ }^{3}$ Medina Nur Asyifah Purnama, Transformasi Pendidikan Islam PersePektif K.H. Imam Zarkasyi Dalam Pengembangan Pesantren Modern Gontor, (Tesis, UIN Maulana Malik Ibrahim Malang, 2013), 3 .
} 
351 | Isnaning Tyastuti / Pesantren dan Tantangan Modernisasi...

dinamisasi dan modernisasi pesantren.Dalam hubungan ini, penulis ingin mengkaji pesantren dan tantangan modernisasi melalui pemikiran K.H. Abdurrahman Wahid atau yang lebih dikenal dengan sebutan Gus Dur. Untuk mengetahui hal-hal tersebut diatas, penulis mencoba meneliti pemikiran Gus Dur tentang pesantren dan tantangan modernisasi dalam Buku MenggerakkanTradisi: Esai-Esai Pesantren.

\section{Tentang Pesantren}

Pesantren adalah sebuah kehidupan yang unik, sebagaimana dapat disimpulkan dari gambaran lahiriahnya.Pesantren adalah sebuah kompleks dengan lokasi yang umumnya terpisah dari kehidupan sekitarnya.Pesantren merupakan lembaga pendidikan tradisonal yang didalamnya terdapat beberapa unsur sebagai sendisendi pelengkap lembaga tersebut dikatakan pesantren.Adanya santri, kyai, pondok, pesantren,masjid sebagai pusat pedidikan dilembaga tersebut,serta adanya kitab-kitab kuning sebagai ciri khas lembaga yang dinamakan pesantren.Pesantren adalah sebuah kompleks dengan lokasi yang umumnya terpisah dari kehidupan sekitarnya. Dalam kompleks itu berdiri beberapa buah bangunan rumah kediaman pengasuh (di daerah berbahasa Jawa disebut kiai, di daerah berbahasa Sunda anjengan, dan di daerah berbahasa Madura nun atau bendara, disingkat ra), sebuah surau atau masjid, tempat pengajaran diberikan (bahasa Arab madrasah, yang juga terlebih sering mengandung konotasi sekolah); dan asrama tempat tinggal para siswa pesantren (santri, pengambil alihan dari bahasa Sansekerta dengan perubahan pengertian). ${ }^{4}$

Jika dilihat dari sejarah panjang pendidikan di Indonesia, pendidikan pesantren menjadi sesuatu yang wajib masuk dalam setiap kajian perkembangan pendidikan.Bagaimanapun pendidikan pesantren adalah pendidikan tertua yang pernah ada di Indonesia dan dianggap sebagai produk budaya Indonesia yang murni.Kehadiran pesantren untuk merespon terhadap situasi dan kondisi suatu masyarakat yang dihadapkan pada runtuhnya sendi-sendi moral atau bisa menjadi bangsa yang bermartabat.Untuk mengatasi hal ini, lembaga pendidikan adalah

\footnotetext{
${ }^{4}$ Abdurrahman Wahid, Menggerakkan Tradisi, (Jogjakarta: LKis, 2010), 3.
} 
salah satu media penting yang dapat membentuk bagaimana corak pandangan hidup seseorang atau masyarakat.Oleh karena itu, pesantren dalam jangka panjang berada dalam kedudukan kultural yang relatif lebih kuat dalam kehidupan masyarakat di sekitarnya. Kedudukan ini dapat dilihat dari pesantren yang mampu melakukan transformasi total dalam sikap hidup masyarakat sekitarnya, tanpa ia sendiri harus mengorbankan identitas dirinya. ${ }^{5} \mathrm{Di}$ samping itu, pesantren juga merupakan lembaga pendidikan Islam yang memiliki akar secara historis yang cukup kuat sehingga menduduki posisi relatif sentral dalam dunia keilmuan. Pada transformasi sosial dan budaya yang dilakukan pesantren pada proses berikutnya melahirkan dampak-dampak baru dan salah satunya reorientasi yang semakin kompleks dari seluruh perkembangan masyarakat. Bagian dari reorientasi dari fungsi dan tujuan tersebut digambarkan oleh Abdurrahman Wahid, diantaranya pesantren memiliki peran mengajarkan keagamaan, yaitu nilai dasar dan unsurunsur ritual Islam.Dan pesantren sebagai lembaga sosial budaya, artinya fungsi dan perannya ditujukan pada pembentukan masyarakat yang ideal. Menurut KH. Abdurrahman Wahid dalam esai-esainya yaitu pesantren sebagai proyek pilihan ideal bagi pola kehidupan umum yang dilanda krisis di masyarakat sekitarnya, akhirya menimbulkan pesantren sebagai unit budaya yang berdiri terpisah dari dan pada waktu yang bersamaan menjadi bagian dari kehidupan bermasyarakat.Peranan berganda inilah yang sebenar-benarnya dapat dikatakan menjadi ciri utama pesantren sebagai sebuah subkultur.

KH. Abdurrahman Wahid menegaskan dalam bukunya bahwa peran pesantren dalam melakukan perkembangan metode dakwah di mayarakat dalam bidang keilmuan dan pengembangannya guna menjaga pola kehidupan masyarakat menggunakan metode dua hal yaitu dalam menjalankan peranan ganda ini, pesantren terlibat dalam proses penataan tata nilai yang memiliki dua unsur utama. Pertama, peniruan adalah usaha yang dilakukan secara terusmenerus secara sadar untuk memindahkan pola kehidupan para sahabat Nabi Saw.dan para ulama salaf ke dalam praktik kehidupan di pesantren. Kedua, pengekangan yang memiliki perwujudan utama dalam disiplin sosial yang ketat di

${ }^{5}$ Ibid.. 10. 
pesantren. ${ }^{6}$ Penunjangan kehidupan pesantren dibagi menjadi dua jenis yaitu, warga pesantren dan warga masyarakat luar pesantren yang memiliki hubungan erat dengan pesantren. ${ }^{7}$ Yang dimaksud warga pesantren adalah kyai (ajengan, nun, atau bendara) yang menjadi pengasuh, ustadz, sebagai guru, dan para santri, sedangkan yang disebut warga masyarakat di luar pesantren adalah mereka yang hidup berada di luar wilayah pesantren namun secara letak berdekatan dengan pesantren dan mengetahui pola kehidupan di pesantren. Bagi warga masyarakat di luar pesantren, kehidupan di pesantren merupakan gambaran ideal yang tidak mungkin dapat digambarkan dalam kehidupannya sendiri; dengan demikian pesantren adalah tempat yang dapat memberikan kekuatan spiritual kepadanya pada saat-saat tertentu terutama dalam menghadapi kemalangan dan kesukaran.Selain itu, pesantren sebagai sumber inspirasi bagi sikap hidup yang diinginkan dapat tumbuh dalam diri anak-anaknya, terlebih lagi jika sistem pendidikan di luar pesantren tidak memberikan harapan besar bagi terjangkaunya ketenangan dan ketentraman hidup mereka.Inilah yang menjadi hal ketertarikan masyarakat terhadap pesantren pada umumnya. ${ }^{8}$

\section{Modernisasi Menurut KH. Abdurrahman Wahid}

Di zaman modern ini, modernisasi merupakan salah satu prasyarat bagi kebangkitan kaum muslim. Oleh karena itu pemikiran dan kelembagaan pendidikan Islam, salah satunya adalah pesantren haruslah dimodernisasi atau dengan kata lain harus disesuaikan dengan kerangka modernitas, karena mempertahankan kelembagaan Islam tradisional hanya akan memperpanjang ketidakmampuan kaum muslim dalam menghadapi tantangan zaman modern dan kemajuan ilmu pengetahuan dan teknologi seperti saat ini. Dalam memaknai kata modernisasi KH. Abdurrahman Wahid juga memaknai sebagai proses menuju kesempurnaan. Menjaga nilai-nilai kehidupan yang sudah ada kemudian dalam era modern ini dikembangkan dengan tanpa meninggalkan ciri khas itu sendiri.Modernisasi merupakan bagian dari kata dinamisasi yang pada dasarnya

\footnotetext{
${ }^{6}$ Ibid., 13.

${ }^{7}$ Ibid., 16.

${ }^{8}$ Ibid., 32.
} 
mencakup dua buah proses, yaitu penggalakan kembali nilai-nilai hidup positif yang telah ada, selain mencakup pula pergantian nilai-nilai lama itu dengan nilainilai baru yang dianggap lebih sempurna. Proses penggantian nilai itu dinamai modernisasi. Jelaslah dari keterangan ini bahwa pengertian modernisasi sebenarnya telah terkandung dalam kata dinamisasi. Sedangkan kata dinamisasi itu sendiri, dalam penggunaannya di sini akan memiliki konotasi atau mafhum perubahan ke arah kesempuranaan keadaan, dengan menggunakan sikap hidup dan peralatan yang telah ada sebagai dasar. Dikemukakan prinsip itu di sini, karena ada keyakinan, konsep-konsep yang dirasa asing oleh pesantren, akanmenghadapi hambatan luar biasa nantinya. Kita percaya, pendekatan untuk memperoleh penerimaan dari pesantren sendiri, dalam jangka panjang akan memberikan hasil yang lebih baik daripada konsep mana pun juga. ${ }^{9}$

Selanjutnya untuk mengemukakan tentang bagaimana seharusnya proses dinamisasi itu berlangsung perlu adanya langkah-langkah sebagai berikut: ${ }^{10}$ Pertama, perbaikan keadaan di pesantren sebenarnya bergantung sebagian besar pada kelangsungan proses regenerasi yang sehat dalam pimpinannya. Yang dimaksud dengan regenerasi pimpinan yang berlangsung dengan sehat adalah pergantian pemimpin secara bertahap dan teratur, yang memungkinkan penumbuhan nilai-nilai baru dalam kehidupan pesantren secara konstan. Pemimpinan muda di pesantren, bila mana disertakan dalam proses memimpin secara berangsur-angsur, akan mampu menciptakan perpaduan antara kebutuhan praktis akan kemajuan (terutama material ) dan antara tradisi keagamaan yang mereka warisi dari generasi sebelumnya. Yang menjadi persoalan penting sekarang ini adalah bagaimana menyertakan pemimpinpemimpin muda pesantren dalam forum-forum semacam ini secara tetap dan massif.

Kedua, prasayarat utama bagi suatu proses dinamisasi berluas lingkup penuh dan dalam adalah rekonstruksi dan bahan pengajaran ilmu-ilmu agama dalam skala besar-besaran. Dari tingkatan dasar hingga perguruan tinggi, para

\footnotetext{
${ }^{9}$ Ibid., 53.

${ }^{10}$ Ibid., 63 .
} 
355 | Isnaning Tyastuti / Pesantren dan Tantangan Modernisasi...

santri disuapi dengan kaidah-kaidah yang sudah tidak mampu mereka cernakan lagi.Penguasaan atas kaidah-kidah itu lalu menjadi masinal, tidak memperlihatkan watak berkembang lagi.Inilah yang justru harus dibuat rekonstruksinya, dengan tetap tidak meninggalkan pokok-pokok ajaran keagamaan yang kita warisi selama ini. ${ }^{11}$ Demikianlah gagasan Gus Dur mengenai dinamisasi pesantren yang didalamnya tercakup pula proses modernisasi.

Selanjutnya untuk melakukan perubahan dalam pendidikan pesantren sebagai respon terhadap modernisasi, Gus Dur berpendapat setidaknya pesantren harus mengawali dan dalam hal ini pesantren yang juga merupakan lembaga pendidikan Islam menjadi pewaris tradisi intelektual Islam tradisional.Pesantren juga dipandang sebagai tempat belajar agama secara mendalam dan lebih lanjut tentang ilmu agama Islam yang diajarkan secara sistematis.Namun, pendidikan pesantren tradisional mempunyai ciri belum dapat dikelola dengan professional, lebih cenderung mengendalikan figur kyai atau ulama dan kurikulum yang terfokus pada kajian ilmu agama saja.Seiring dengan kemajuan zaman dan teknologi, pesantren semakin mengalami perkembangan yang pesat dengan tanpa meninggalkan ciri khas pesantren.Dinamika perubahan masyarakat semakin dituntut untuk mengikuti perkembangan zaman dengan sangat cepat.

\section{Pesantren dan Tantangan Modernisasi Menurut KH. Abdurrahman Wahid}

Mengolah konsep apapun tentang pesantren, sebenarnya bukan hal yang mudah. Baik karena pertumbuhannya yang unik maupun karena tertinggalnya ia dari lembaga kemasyarakatan lainnya dalam melakukan kegiatan-kegiatan teknis, pesantren belum lagi mampu mengolah dan kemudian melaksanakan konsep berdasarkan pertimbangan akal belaka, bagaimanapun sistematis dan modisnya sistem itu. Setidaknya untuk generasi ini, semua konsep yang bersifat demikian akan menghadapi hambatan-hambatan luar biasa dalam pelaksanaanya ketika menghadapi proses dimamisasi atau modernisasi. ${ }^{12}$ Dalam melihat perkembangan pesantren dewasa ini membutuhkan waktu berevolusi cukup lama.Dengan

\footnotetext{
${ }^{11} \mathrm{Ibid}$.

${ }^{12}$ Ibid., 51.
} 
memikirkan konsep yang tepat dan dominan guna mengisi kegiatan-kegiatan kepesantrenan di era serba modern dan kemajuan ilmu pengetahuan dan teknologi (IPTEK) zaman sekarang. Proses modernisasi suatu lembaga kemasyarakatan lebih-lebih seperti pesantren ini adalah suatu usaha yang rumit dan memakan waktu lama. Tidak ada sebuah konsep pun mengalami perubahan-perubahan dalam pelaksanaannya kemudian. Oleh karena itu, dalam kesempatan ini tidakakan ditemui suatu anggapan bahwa kita telah menemukan suatu konsep final yang dapat dipertanggungjawabkan kebenarannya secara ilmiah. Yang akandikemukakan hanyalah sekedar gambaran mengenai langkah-langkah apa saja yang dapat diambil untuk memulai proses dinamisasi secara berencana. ${ }^{13}$

Untuk dapat menemukakan suatu konsep yang relevan bagi kebutuhan pesantren, kita harus mengetahui terlebih dahulu garis besar situasi yang dihadapi oleh pesantren dewasa ini. Menurut KH. Abdurrahman wahid Situasi kejiwaan yang dihadapi oleh pesantren dewasa ini adalah meluasnya rasa tidak menentu yag biasa disebut keadaan rawan. Diantaranya ${ }^{14}$ : Pertama, sebagai pantauan keadaan rawan yang memang melanda kehidupan bangsa kita pada umumya sekarang ini. Akibat kedudukan kita dalam suasana tradisional dewasa ini.Kedua, kesadaran akan sedikitnya kemampuan untuk mengatasi tantangan-tantangan yang dihadapi oleh pesantren, terutama tantangan yang dihadapi oleh kemajuan teknik yang mulai dikonsumsi oleh bangsa kita. Ketiga, statis atau bekunya struktur sarana-sarana yangdihadapi pesantren pada umumnya.Baik sarana yang mencakup menejemen atau kepemimpinan yang terampil maupun sarana materiil (termasuk keuangan) masih berada pada kualitas yang sangat terbatas.Keterbatasan inilah yang membawa akibat tidak mungkin dilakukannya penanganan kesulitan yang dihadapi secara integral atau menyeluruh.Keempat, sulitnya mengajak masyarakat tradisional yang berafiliasi pada pesantren kearah sikap hidup yang lebih serasi dengan kebutuhan-kebutuhan nyata pesantren, padahal pesantren tidak akan mungkin melakukan kegiatan berarti tanpa dukungan dan bantuan mereka, dalam keadaanyang sekarang ini.

\footnotetext{
${ }^{13} I b i d ., 52$.

${ }^{14}$ Ibid., 54 .
} 
357 | Isnaning Tyastuti / Pesantren dan Tantangan Modernisasi...

Jika keadaan rawan ini tidak segera diatasi maka akan lebih sulit lagi bagi pesantren untuk menghadapi tantangan-tantangan yang ada. Mengingat perkembangan masa justru akan semakin memperkuat kadar dan luas lingkup tantangan itu. Menurut KH. Abdurrahman Wahid perubahan kadar tantangan ini dalam kalangan sosiologi dinamakan kesenjangan masa (time lag) yang akan menjuruskan keadaan rawan kepada bahaya yang lebih besar. Yakni manifestasi keadaan rawan sekarang ini adalah semakin meluasnya cetusan frustasi yang mendambakan penyelesaian. Frustasi ini jika tidak menemukan penyelesaian akanberubah menjadi rasa masa bodoh (epati) terhadap mati hidupnya pesantren menjadi keadaan hilang semangat untuk maju. Karena kurangnya semangat untuk maju adalah modal utama pengembangan atau lembaga kemasyarakatan maka akan berakibat fatal bagi pesantren. ${ }^{15}$

Manifestasi umum dari keadaan rawan di pesantren tampak pada dua reaksi terhadap nilai-nilai kehidupan yang berada pada masa transisi atau masa pergeseran dari masa lama kemasa modern pada dewasa ini. KH. Abdurrahman Wahid mengungkapkan keadaan rawan tersebut yang dikutip dalam bukunya diantaranya : Pertama, menutup diri dari perkembangan umum masyarakat luar terutama dari kehidupan yang mengancam kemurnian kehidupan beragama. Reaksi kedua, justru mempergiat reaksi solidaritas (solidarity making) yang kuat antar pesantren dan masyarakat. Penggalan proses ini disertaipula sikap hidup meninjolkan hal-hal modern secara lahiriyah. Teknik dan cara modernisasi diridikembangkan sedemikian rupa sehingga tidak dapat dihindari kesan adanya sinobisme di sementara kalangan pesantren. ${ }^{16}$ Kedua reaksi tersebut tersebut menunjukkan dengan nyata kepada kita bahwa pesantren tidak memiliki pimpinan yang efektif, yang ditunduki oleh semua pihak.Ketiadaan tokoh yang dapat menjadi pimpinan yang dapat ditunduki bersama, selain faktor polarisasi sosiopolitis yang melanda umat Islam yang melanda watak kepemimpinan pesantren yang memang bertopang pada kekuatan moral (bukannya bertopang pada kemampuan berorganisasi), adalah sebab dari ketiadaan kepemimpinan itu.Selain

\footnotetext{
${ }^{15} \mathrm{Ibid}$., 55 .

${ }^{16}$ Ibid., 56 .
} 
itu pola pengelolaan pesantren dari sisi kurikulum pendidikannya mau tidak mau harus melakukan perubahan yang inovatif yaitu mempadukan pendidikan pesantren dengan pendidikan umum, guna mewadai kebutuhan santri dalam melengkapi pendidikannya yang menjadi urgen dalam menghadapi era modern ini.Arus perkembangan masyarakat yang berkembang begitu cepat membuat pesantren mau tidak mau harus menyesuaikan diri dengan cepat. Pendirian sekolah umum di pesantren dapat dilakukan dengan memadukan ilmu-ilmu agama dengan pengetahuan umum, hal ini sangatlah penting dan perlu dilakukan mengingat mayoritas santri yang belajar di pesantren tidak semua bertujuan menjadi kiai, dengan begitu santri memiliki kemampuan lain agar lebih dapat mengembangkan potensi dirinya, memindahkan titik berat kurikulum pada orientasi yang bersifat melulu keagamaan, tidak berarti akan terjadinya perubahan besar dalam kualitas siswa yang ditampung oleh madrasah. Paling banyak hanya akan terjadi perubahan kualitatif belaka, sebagai hasil perubahan orientasinya. Adalah lebih realistis untuk mendorong pesantren agar menciptakan dan mengelola sekolah-sekolah baru yang bersifat umum.

Pada awal tahun 1970-an muncul fenomena perubahan dan perkembangan pendidikan pesantren dengan adanya integrasi sekolah umum ke dalam pendidikan pesantren, yang terkenal dengan sebutan pondok modern. Pondok modern merupakan perpaduan model klasikal pesantren yang khas dengan sistem pendidikan modern.Pendidikan pesantren klasikal merupakan pendidikan yang masih menggunakan sistem sorogan, bondongan. Sedangkan pesantren modern adalah yang telah memasukkan sistem pendidikan formal seperti halnya pesantren Darussalam Gontor, yang merupakan salah satu pesantren yang mengintegrasikan sekolah umum dengan pesantren.Pengintegrasian sekolah umum ke dalam pendidikan pesantren merupakan upaya sadar yang dilakukan pesantren dalam merespon laju perkembangan agar tetap eksis dalam dunia modern dan untuk mempersiapkan lulusannya berkualitas dalam mengarungi kehidupannya di era modern ini. Pengintegrasian sekolah umum ke dalam pesantren akan berpengaruh kepada kelangsungan pesantren itu sendiri. Zamakhsyari Dhofier melaporkan bahwa kebanyakan pesantren kecil mati pada 1950-an. Salah satu penyebabnya 
dikarenakan kebijakan pemerintah yang mengembangkan sekolah umum seluasluasnya, akibatnya anak muda yang belajar di pesantren menurun di era Desember 1949 sebab memilih pendidikan sekolah umum. ${ }^{17}$

Pesantren-pesantren besar dapat bertahan, tetapi hanya dengan memasukkan lembaga-lembaga pendidikan umum di dalamnya. Akan tetapi ada juga pesantren yang menolak mengintegrasikan sekolah umum ke dalam pesantren dengan dua alasan utama yaitu: pertama, tidak sesuainya sekolah umum tersebut dengan tujuan keagamaan yang dimiliki pesantren. Kedua, ketidakmampuan pesantren mengelola sekolah umum. Bukan tidak beralasan mengapa ada pesantren menolak adanya integrasi sekolah umum ke dalam pesantren, ini dikarenakan ketika banyak santri mengirim surat dengan huruf latin sebagai akibat adanya proses "sekularisasi" (didirikannya SMP, SMA, dan PGA), sehingga banyak wali murid yang mulai gelisah. Mereka gelisah karena menganggap anaknya sudah meninggalkan ciri kepesantrenan.

Jalan keluar yang bisa diterapkan pesantren terkait dua alasan keengganan pesantren mengintegrasikan pendidikan umum dalam pendidikan pesantren, yaitu dengan jalan menunjukkan kenyataan bahwa dalam sistem pendidikan agama yang paling eksklusif sekalipun, tidak semua siswanya dapat dicetak menjadi seorang ahli agama atau ulama dan melalui penyesuaian serta peningkatan cara kerja. Solusi yang tidak pernah terpikirkan oleh para pemerhati pesantren sebelumnya.Ketika pesantren dapat diintegrasikan dengan sekolah umum setidaknya ada manfaat yang dapat di ambil dari program tersebut. Mereka siswa yang notabene hanya mengikuti sekolah umum setidaknya akan mendapat pengetahuan agama dari kegiatan ekstra yang diberikan berjenjang sesuai dengan jenjang sekolah umum yang di lalui. Dan bagi siswa yang ingin menjadi ulama maka dapat memperlajari ilmu-ilmu agama secara lebih dalam dengan bentuk pendidikan formal di madrasah dan mengikuti pengajian- pengajian yang diberikan.Selain itu juga dengan memberikan kesempatan kepada calon-calon ulama untuk mengejar cita-cita mereka, selain memberikan kesempatan kepada para siswa yang belajar di sekolah umum untuk belajar, menurut bakat masing-

${ }^{17}$ Zamakhsyari Dhofier, Tradisi Pesantren, (Jakarta: LP3ES, 2015), 75. 
masing, pesantren dapat membantu mengisi kurangnya wadah pendidikan formal bagi generasi muda kita.Dalam sensus kelembagaan pendidikan dasar oleh pemerintah (Bappenas), Madrasah Ibtidaiyah (MI) secara berdampingan dengan Sekolah Dasar (SD).

Dapat kita perkirakan bahwa harapan akhirnya adalah menuju pemberdayaan secara optimal lembaga ini untuk membangun sumber daya manusia Indonesia.Inilah salah satu fakta ilustratif keberadaan dan posisi madrasah sebagai salah satu wujud etnis budaya Indonesia.Secara teknis madrasah menggambarkan secara formal yang tidak berbeda dengan sekolah.Hanya dalam lingkup kultural, madrasah memiliki konotasi spesifik.Di lembaga ini anak memperoleh pembelajaran hal ihwal atau seluk-beluk agama dan keagamaan.Secara birokratik, madrasah-madrasah berada di bawah naungan Kemantrian dan Departemen Agama.Sementara sekolah-sekolah pada umumnya berada di bawah naungan departemen pendidikan Nasional.Madrasah dalam hal ini (MI, MTs, MA) berada dalam naungan pesantren atau pondok pesantren. Madrasah yang berada dalam naungan pesantren memberi kesempatan kepada para siswanya (santri) untuk menambah kekurangan ilmu pengetahuan agama melalui pengajian-pengajian kitab di luar jam madrasah dibawah bimbingan para kiai atau ustadz.

Dengan tinggal di pondok pesantren, siswa madrasah dapat memperoleh bimbingan dan kesempatan menjalankan agama lebih intensif.Demikianlah, realitas madrasah menampilkan sosok beragam sebagai dampak diverisikasi pendidikan yang berlangsung di dalamnya.Oleh karena itu, tidaklah mengherankan bila saat ini pesantren tengah bersentuhan dengan madrasah atau sekolah dari tingkat sekolah lanjutan pertama hingga perguruan tinggi.Pesantren jenis ini dikenal dengan sebutan pondok pesantren modern. Dengan kata lain, pondok pesantren kini telah mengalami perubahan bentuk dari keadaan semula.

Melihat kondisi demikian, serta dalam menyikapi perkembangan zaman pada saat sekarang, pesantren dalam mengatur strategi untuk tetap memiliki eksistensi kuat di dunia pendidikan perlu adanya melakukan perubahan dalam pendidikan pesantren sebagai respon terhadap modernisasi Gus Dur berpendapat 
setidaknya pesantren harus mengawali dan menekankan pada hal-hal sebagai berikut :

\section{Memasukkan sekolah umum ke dalam pesantren}

Dunia pendidikan kita dewasa ini masih berada dalam taraf yang boleh dikata kritis.Dengan banyaknya jumlah anak didik yang putus sekolah (drop out), kemampuan kita semua untuk menyediakan kesempatan kerja yang lebih merata juga menjadi lebih terbatas lagi.Belum pula diingat bahwa di antara mereka yang dapat melanjutkan sekolah masih cukup banyak didapati ketimpangan antara kemampuan, biayanya, dan motivasinya. ${ }^{18}$ Oleh karena itu, seluruh kemampuan untuk membuka lembaga-lembaga pendidikan berupa sekolah harus digali terus - menerus dari masyarakat, baik yang berasal dari dana pemerintah (sekolah negeri) maupun nonpemerintah (sekolah swasta). Untuk menggali kemungkinan mendirikan sekolah-sekolah baru dalam jumlah besar, sebenarnya dapat ditempuh pemecahan lain yang bersifat lebih langsung. Pemecahan tersebut adalah yang berbentuk ajakan serius pada pesantren untuk mendirikan sekolah umum di lingkungan masing-masing.Pesantren memiliki kemampuan potensial untuk mengarahkan dana-dana yang diperlukan untuk tujuan tersebut dari masyarakat, jika pesantren sendiri bersedia melaksanakannya.

\section{Pengembangan Kurikulum Pesantren}

Kurikulum yang berkembang di pesantren selama ini memperlihatkan sebuah pola yang tetap. Pola itu dapat diringkas ke dalam pokok-pokok berikut ${ }^{19}$ : Pertama, Kurikulum ditujukan untuk mencetak ulama di kemudian hari. Kedua, Struktur dasar kurikulum itu adalah pengajaran pengetahuan agama dalam segenap tingkatannya dan pemberian pendidikan dalam bentuk bimbingan kepada santri secara keseluruhan. Ketiga, kurikulum yang ada berwatak lentur atau fleksibel, dalam artian setiap santri berkesempatan menyusun kurikulumnya sendiri

\footnotetext{
${ }^{18}$ AbdurrahmanWahid, MenggerakkanTradisi..., 65.

${ }^{19}$ Ibid., 151.
} 
sepenuhnya atau sebagian sesuai dengan kebutuhan dan kemampuannya, bahkan pada pesantren yang memiliki sistem pendidikan berbentuk sekolah sekalipun. Kurikulum telah banyak mengalami perubahan dan berkembang dalam variasi bermacam-macam, tetapi kesemua perkembangan itu tetap mengambil bentuk pelestarian watak utama pendidikannya sebagai tempat menggembleng ahli-ahli agama formasi total atas kehidupan masyarakat di tempat masing-masing.

Beberapa jenis kurikulum utama perlu ditinjau sepintas lintas dalam hubungan ini :pertama, Kurikulum pengajian non sekolah, dimana santri belajar pada beberapa orang kiai/guru dalam sehari semalamnya. Sistem pendidikan seperti ini, yang dinamai sistem lingkaran (pengajian halaqah) memberikan kebebasan sepenuhnya kepada santri untuk membuat kurikulumnya sendiri, dengan jalan menentukan sendiri pengajian mana yang akan diikutinya. Kedua, Kurikulum sekolah tradisional (madrasah salafiyah), dimana pembelajaran telah diberikan di kelas dan disusun berdasarkan kurikulum tetap yang berlaku untuk semua santri.Akan tetapi, ini tidak berarti pendidikannya sendiri telah menjadi klasikal, karena kurikulumnya masih didasarkan pada penahapan dan penjejangan berdasarkan urut-urutan teks kuno secara berantai. Ketiga, Pondok modern, dimana kurikulumnya telah bersifat klasikal dan masingmasing kelompok mata pelajaran agama dan nonagama telah menjadi bagian integral dari sebuah sistem yang telah dibuat dan berimbang. Akan tetapi, di sini pun mata pelajaran nonagama, walaupun telah diakui pentingnya, masih ditundukkan pada kebutuhan penyebaran ilmu-ilmu agama, sehingga kelompok adalah mata pelajaran tersebut memiliki perwatakan intelektualistis dengan tekanan pada penumbuhan ketrampilan skolastis.

Melihat tiga buah kurikulum utama yang berkembang di pesantren pada umunya tersebut setidaknya ada lima percobaan yang dapat dilakukan untuk mengembangkan kurikulum pesantren secara lebih 
363 | Isnaning Tyastuti / Pesantren dan Tantangan Modernisasi...

dinamis yaitu ${ }^{20}$ : Pertama, Madrasah negeri. Sistem pendidikan ini telah lama dikembangkan dan telah berusia belasan tahun, tetapi belum memiliki pola menetap, karena senantiasa mengalami perubahan kurikulum dalam jarak telalu dekat. Pendidikan nonagama didalamnya mengikuti pola kurikulum sekolah-sekolah nonagama, tetapi secara kualitatif hasilnya belum lagi memuaskan. Masih terlalu pagi untuk mengetahui hasil apa yang dapat diharapkan dari sistem pendidikan ini dalam hubungannya dengan penyediaan angkatan kerja, karena percobaan terakhir untuk membuat kurikulumnya relavan dengan kebutuhan baru saja dijalankan. Kedua, Program ketrampilan di pesantren. Program ini, yang dapat dilaksanakan sebagai kegiatan kurikuler sistem pendidikan sekolah di pesantren maupun sebagai kegiatan nonkurikuler, dimaksudkan untuk menyediakan sarana memperoleh ketrampilan yang diperlukan untuk hidup atas kaki sendiri dalam kehidupan setelah keluar dari pesantren nanti.

Orientasi kehidupan pada kerja nyata juga diharapkan akan dihasilkan oleh pendidikan ketrampilan di pesantren ini. Struktur pendidikannya juga sangat sederhana : penyediaan program terminal berjangka sangat pendek untuk masing-masing jenis ketrampilan yang diajarkan. Jika direncanakan secara tepat, program ini sebenarnya memiliki kemungkinan berkembang menjadi unsur luar sekolah yang penting bagi pesantren, sebagai semacam program deschooling di mana kegiatan ketrampilan tidak terlalu direncanakan secara kaku dengan menggunakan tenaga pengajar formal, melainkan cukup dilayani oleh tukang-tukang dan perajin dari masyarakat sekitar pesantren sendiri. Konsep pendidikan ketrampilan yang seperti ini akan mirip dengan gagasan sekolah-masyarakat (community schools) yang dicetuskan akhirakhir ini. Ketiga, Program penyuluhan dan bimbingan. Berbeda dengan program ketrampilan yang ditujukan kepada seroang santri sebagai individu, program ini ditujukan pada pemberian peranan kepada santri 
sebagai penyuluh dan pembimbing pengembangan beberapa jenis profesi di masyarakat. Dalam program ini, para santri secara bergiliran dididik bersama-sama dengan para petani dan perajin dari masyarakat dalam bimbingan untuk mengembangkan profesi mereka, dengan mengundang tenaga pembimbing dari luar. Keempat, Program sekolah-sekolah nonagama di pesantren, dasar dari program ini adalah penilaian lebih baik bagi pesantren untuk mendirikan sekolah-sekolah nonagama dalam lingkungannya daripada bertindak setangah-setengah seperti kebanyakan pesantren dengan berbagai jenis madrasah mereka.

Sebagai kegiatan nonkurikuler, pengajaran pengetahuan agama dapat diberikan di luar sekolah dalam lingkungan pesantren sendiri. Sebagai program yang mengintegrasikan sekolah nonagama ke dalam sistem pendidikan pesantren tradisional, diharapkan para santri yang mengikutinya akan kampu menguasai pengetahuan dasar tentang agama pada waktu mereka menyelesaikan sekolah nonagama mereka di pesantren. Kelima, Program pengembangan masyarakat oleh pesantren. Program ini bermaksud menciptakan tanaga-tenaga pembangunan masyarakat (change agents) dari pesantren, yang bertugas membantu warga desa untuk mengenal dan memanfaatkan potensi yang mereka miliki untuk memperbaiki kehidupan mereka, dengan jalan merencanakan dan melaksanakan proyek-proyek pengembangan desa mereka. Dalam konteks yang lebih besar sedikit, para santri dididik untuk merencanakan pembuatan UDKP pada tingkat kecamatan. Program ini baru dicoba dilaksanakan di sebuah pesantren dewasa ini, tetapi ia diharapkan akan dapat diperluas dengan cepat ke banyak pesantren lain nantinya.

Demikianlah KH. Abdurrahman Wahid dalam menjelaskan betapa pentingnya pesantren dimodernisasi dengan tanpa meninggalkan ciri khas yang menjadi tanda pengenal pendidikan tradisional Indonesia yang merupakan peninggalan asli Indonesia dengan dinamika yang identik dengan kemajuan zaman dan mengalami peradaban yang dinamis ke atas. 
365 | Isnaning Tyastuti / Pesantren dan Tantangan Modernisasi...

\section{PENUTUP}

Dari paparan di atas dapat diambil kesimpulan bahwa Pesantren dewasa ini mengalami beberapa tantangan yang merupakan produk dari perkembangan zaman yang signifikan terutama dalam hal ilmu pengetahuan dan teknologi yang sangat mempengaruhi kuat pada dinamika pendidikan khususnya pesantren. Dalam hal ini KH. Abdurrahman Wahid melakukan beberapa tindakan dalam menangani kelangsungan pendidikan pesantren dengan memodernisasikan menejemen atau pola pesantren. Yakni integrasi sekolah umum ke dalam pesantren dan mengembangkan kurikulum dalam pesantren. Dan beberapa langkah dalam pengembangan kurikulum pesantren yaitu; pertama, Kurikulum pengajian non sekolah, Kedua, Kurikulum sekolah tradisional (madrasah salafiyah), Ketiga, Pondok modern. Sehingga dengan langkah sedemikian diharapkan pondok pesantren mampu bertahan seiring perkembangan zaman yang seba modern dan menuntut eksistensi dan kelangsungan pesantren di era global.

Dalam menjalankan programnya, pondok pesantren sebagai lembaga pendidikan dalam mentransformasi ilmu-ilmu keagamaan hendaklah mampu melakukan inovasi yang kreatif, aktif secara universal agar keberadaan pesantren tetap ada walau dalam kurun waktu yang lama di era modern ini. Pesantren saat ini telah mengalami perubahan dengan konsep modernisasi kurikulum dan model kepemimpinannya, dan dalam jangka lama pesantren harus mengalami pembaharuan dalam mengembangkan konsep kurikulum pendidikan di pesantren yang diselaraskan dengan kebutuhan zaman. Bagaimana pesantren mampu merevitalisasi kurikulum berbasis sains guna memajukan peradaban pendidikan bangsa, pesantren juga perlu untuk merevitalisasi kurikulum berbasis humaniora guna menanggapi kepentingan kehidupan sosial pada peradaban manusia di era modernisasi ini.

\section{DAFTAR RUJUKAN}

Azra, Azyumardi. 2012. PENDIDIKAN ISLAM Tradisi dan Modernisasi di Tengah Tantangan Milenium III. Jakarta: Prenada Media Group.

Dhofier, Zamakhsyari. 2015. Tradisi Pesantren. Jakarta : LP3ES. 
Al-A dabiya, Volume 13, Nomor 02, Desember 2018 | 366

Furchan, Arif, Maimun, Agus. 2005. Studi Tokoh Mentode Penelitian Mengenai Tokoh. Yogyakarta: PustakaPelajar.

Mardiyah. 2015. Kepemimpinan Kyai Dalam Memelihara Budaya Organisasi). Malang: Aditya Media Publishing.

NurAsyifa P, Medina. 2013. Transformasi Pendidikan Islam PersePektif K.H. Imam Zarkasyi Dalam Pengembangan Pesantren Modern Gontor. Tesis tidak diterbitkan. Malang: Tarbiyah UIN Maulana Malik Ibrahim Malang

Wahid, Abdurrahman. 2001. Menggerakkan Tradisi: Esai-Esai Pesantren. Jogjakarta: LKiS. 